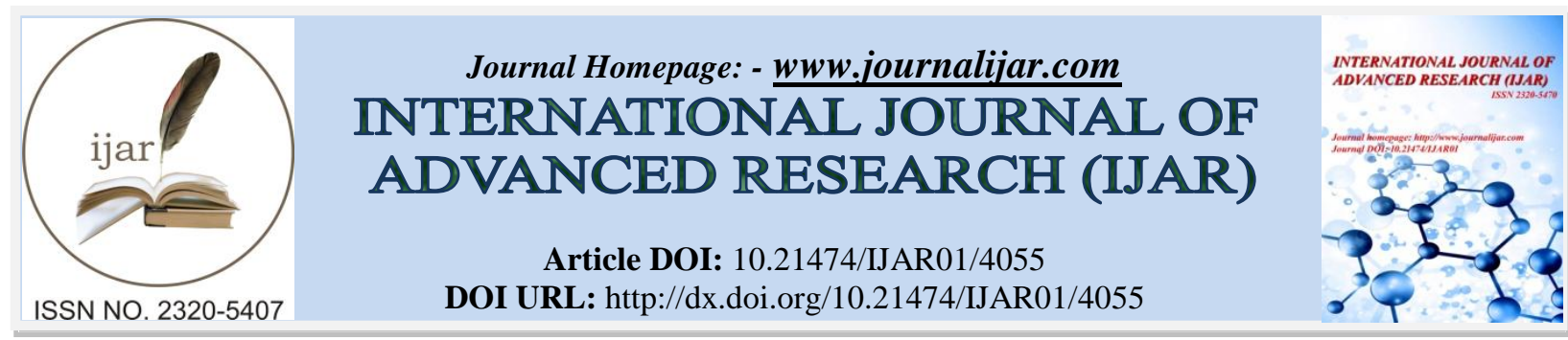

RESEARCH ARTICLE

\title{
ANTI-ULCER ACTIVITY OF BAICALEIN-7-O-GLUCURONIDE ISOLATED FROM PERSICARIA GLABRA FLOWERS AGAINST PYLORIC LIGATION INDUCED ULCER IN ALBINO RATS.
}

\author{
Vijayaraj Chellaiyan* and Senguttuvan Swaminathan
}

Department of Chemistry, Thiru.Vi.Ka. Government Arts College, Thiruvarur, Tamilnadu, India - 610003

\section{Manuscript Info}

Manuscript History

Received: 27 February 2017

Final Accepted: 22 March 2017

Published: April 2017

Key words:-

Baicalein-7-O-glucuronide, Persicaria glabra, Omeprazole, pyloric ligation,

Ulcer index

\begin{abstract}
To isolate a flavonoid glycoside from flowers of Persicaria glabra using chromatography separation techniques, spectral characterization and its anti-ulcer activity. The isolated compound was purified, analyzed and characterized by chemical tests, HPLC and spectroscopic methods such as UV, IR, ${ }^{1} \mathrm{H}-\mathrm{NMR}$ and ${ }^{13} \mathrm{C}$-NMR. Anti-ulcer activity of Baicalein-7- $O$-glucuronide $(250 \mathrm{mg})$ and methanolic extract $(500 \mathrm{mg})$ of Persicaria glabra was examined on pyloric ligated induced ulcer model in rats. Omeprazole was used as standard. The anti-ulcer activity of flower extract of Persicaria glabra was estimated with the help of $\mathrm{pH}$, gastric volume, free acidity, total acidity and ulcer index. The extract showed substantial reduction in $\mathrm{pH}$, gastric volume and ulcer index in dose dependent manner as compared to control. The extract did not produce any toxic effects even at high doses.
\end{abstract}

Copy Right, IJAR, 2017,. All rights reserved.

\section{Introduction:-}

Nature always attitudes as a golden mark to illustrate the outstanding phenomenon of symbiosis. The plant Persicaria glabra belongs to the family Polygonaceae. The family Polygonaceae consists of several important medicinal plants with wide range of biological activities and interesting phyto chemical constituents. The plant mostly found in river banks, stream sides and marshy areas. The plant Persicaria glabra is claimed to have medicinal uses such as astringent, diuretic, treatment of pneumonia, piles, jaundice, rheumatism, relieves pain, and in some areas used as remedy for fever. The root stocks are reported to be used in piles, jaundice, debility and consumption. The herb possess anti-bacterial activity against Micrococcus pyrogens and Diplococcus pyrogens (Sivakumar et al., 2011).

Ulcer is defined as the erosion in the lining of the stomach and is caused by the distractions of the gastric mucosal defense and repair organisms (Anoop and Jegadeesan, 2003). Peptic ulcer disease (PUD) is a disease that affects a considerable number of people worldwide. It progresses when there is an inequality between the aggressive and protective aspects at the luminal surface of the epithelial cells of stomach (Harold et al., 2007).

In recent years, there is a dynamic search to discover novel and alternative agents useful to contest gastric dyspepsia and peptic ulcer disease. Pyloric ligation induced ulcer signifies a unique ulcer model in examining the cause, course, consequence and treatment of peptic ulcer. Pylorus ligation induced ulcer is results of auto digestion of the gastric mucosal barrier possibly due to excess production and accumulation of $\mathrm{HCl}$ in the stomach (Sairam et al., 2003).

Corresponding Author:- Vijayaraj Chellaiyan.

Address:- Department of Chemistry, Thiru.Vi.Ka. Government Arts College, Thiruvarur, Tamilnadu, 
By considering these above and other aspects the present investigation was assumed to evaluate the gastro protective effect of Baicalein-7-O-glucuronide isolated from the flower extracts of Persicaria glabra against pyloric ligation induced gastric ulcer in rats.

\section{Materials and Methods:- Collection of plant material:-}

The fresh flowers of Persicaria glabra were collected in the month of December - January from the area of Cauvery river basin, Thanjavur, Tamilnadu, India. These Plants were identified and authentic by Dr. S. Soosairaj, Assistant Professor, Department of Botany, St.Joseph's College (Autonomous), Bharathidasan University, Trichirappalli, Tamilnadu, India. The voucher specimen (SJCBOT2335) was preserved in our research laboratory for future reference. The collected fresh flower materials were washed appropriately and dried in shade. Dried plant material was subjected to reduction to grainy powdered and kept in airtight container for supplementary use.

\section{Isolation and Identification:-}

The substantial stage in the experimental work embraces first the isolation of chemical substances from the chosen plant and secondly, the characterization of those isolated compounds. The flowers of Persicaria glabra $(2.5 \mathrm{Kg})$


vacuo and the aqueous concentrate was fractionated with peroxide free ether $(5 \times 250 \mathrm{ml})$ and ethyl acetate $(8 \times 250$ ml) (Sigma Aldrich Co., India).

The residue from ethyl acetate segment was taken up in acetone and left in an ice-chest for two days when a yellow solid separated. It eminent a greenish brown colour with alc. $\mathrm{Fe}^{3+}$, formed yellow precipitate with basic lead acetate solution and reduced ammoniacal $\mathrm{AgNO}_{3}$ but not Fehling's solution. It contributed yellow colour with aqueous $\mathrm{NaOH}$ intense yellow with Con. $\mathrm{H}_{2} \mathrm{SO}_{4}$ and magenta colour with $\mathrm{Mg} / \mathrm{HCl}$. It seemed deep purple under UV which revolved yellow and disclosure to $\mathrm{NH}_{3}$. It retorted to Wilson's Boric Acid, Gibbs and Molisch's tests but not answer to Horhammer- Hansel tests.

Supporting intention for the structure of the flavone glycoside is provided by the HPLC (Shimadzu, Columbia), UV (Perkin Elmer Spectrophotometer), IR (Perkin - Elmer spectrometer) and NMR (125 MHz and $500 \mathrm{MHz}, \mathrm{DMSO}-\mathrm{d}_{6}$ ) spectral data were recorded on a Bruker AMX NMR spectrometer. Chemical shifts were reference to the corresponding residual solvent peaks and the values were recorded in $\delta$.

\section{Baicalein-7- $O$ - glucuronide:-}

Yellow solid crystals; m.p. $203^{\circ} \mathrm{C}$; RT $13.88 \min (\mathrm{Fig} 1)$; UV $\lambda_{\max }^{\mathrm{MeOH}}(\log \varepsilon) 230,258 \mathrm{sh}, 331 \mathrm{~nm}$; IR (KBr): $v_{\max }$ $3312,2982,2945,2834,1653,1448,1411,1108,1077$ and $1015 \mathrm{~cm}^{-1} ;{ }^{1} \mathrm{H}-\mathrm{NMR}$ spectrum $\delta(500 \mathrm{MHz}$, DMSO$d 6)$ : Fig $2 ;{ }^{13} \mathrm{C}$ - NMR (125 MHz, DMSO-d6): Fig 3.

\section{Hydrolysis of the glycoside:-}

The glycoside dissolved in hot aqueous methanol was hydrolyzed with $\mathrm{H}_{2} \mathrm{SO}_{4}(5 \%)$ at $100^{\circ} \mathrm{C}$ for around $2 \mathrm{hrs}$. The excess of alcohol was distilled off in vacuo and the succeeding aqueous solution was extracted with ether. The residue from ether fraction was isolated as designated below. The glycoside was subjected to partial hydrolysis by treatment with $10 \%$ formic acid in cyclohexane and the resultant solution extracted with ethyl acetate.

\section{Phytochemical screening of plant extract:-}

A small amount of the dry extract was used for the phytochemical tests (Harborne, 1994) for compounds which contain alkaloids, flavonoids, saponins and glycosides while steroids and tannins are absent in entirely the crude extracts.

\section{Animals:-}

Male albino rats of Wistar strain almost weighing 160-180g were used in this study. They were healthy animals bought from the Indian Institute of Science, Bangalore. The animals were kept in spacious polypropylene cages bedded with rice husk. The animal room was well ventilated and preserved under standard experimental conditions (Temperature $27 \pm 2^{\circ} \mathrm{C}$ and 12 hour light/dark cycle) through the experimental period. All the animals were fed with standard pellet diet and water were provided and libitum. They were familiarized to the environment for one week prior to experimental use (Alaghawani and Naser, 2013). 


\section{Acute toxicity studies:-}

Male albino rats were used to study the acute toxicity of methanolic extract and Baicalein-7-O-glucuronide extracted from Persicaria glabra flowers. Animals were fasted overnight and administered with methanolic extract. Changes in the animal behavior were prominent before and after administration for 24 hours. Treated animals continued further detected for up to 14 days for any toxic symptoms (Turner, 1965).

\section{Pyloric ligation induced ulcer in rats:-}

Animals were divided into four groups, each consisting of six rats. Group-1 treated as control group, received saline orally for 7 days. Group- 2 treated as standard group was received Omeprazole $30 \mathrm{mg} / \mathrm{kg}$ for 7 days. Group 3 and 4 treated as treatment groups were received Baicalein-7- $\mathrm{O}$-glucuronide and methanolic extract from Persicaria glabra in a dose of 250 and $500 \mathrm{mg} / \mathrm{kg}$ for 7 days respectively. Animals in all groups were fasted for 18 hours after the respective assigned treatment and were anaesthetized with diethyl ether at the dose of $35 \mathrm{mg} / \mathrm{kg}$. Ligation was done without causing any wound to the blood supply of the stomach. Animals were allowed to recover and steady in individual cages and were deprived of water during postoperative period. After $4 \mathrm{~h}$ of surgery, rats were surrendered and gastric contents were collected into the centrifuge tubes and centrifuged at $1000 \mathrm{rpm}$ for $10 \mathrm{~min}$ and the $\mathrm{pH}$, free acidity, total acidity of the gastric juice was determined (Nguelefack et al., 2005; Hirohashi et al., 1993). In addition the ulcer index was determined by opening the stomach on greater curvature and scores were given 0 to 3 depending upon the austerity of ulcers.

\section{Statistical analysis:-}

Values were expressed as mean \pm SD for six rats in the each group and statistical significant differences between mean values were determined by one way analysis of variance (ANOVA) followed by the Tukey's test for multiple comparisons. The results were statistically analyzed by Graphpad Instat Software (Graphpad Software, San Diego, CA, USA) version 3 was used and $p<0.01$ was considered to be significant.

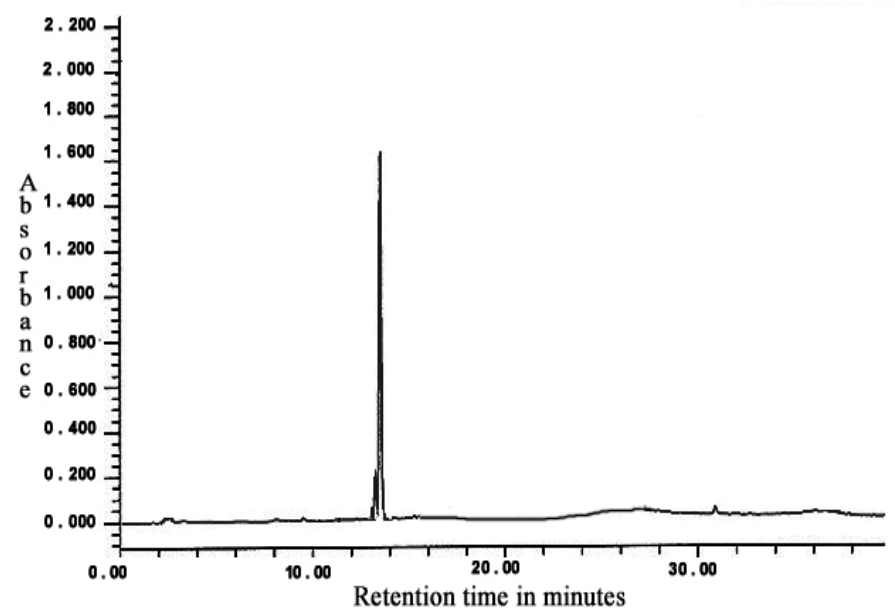

Fig 1:- HPLC of Baicalein-7-O-glucuronide from Persicaria glabra 


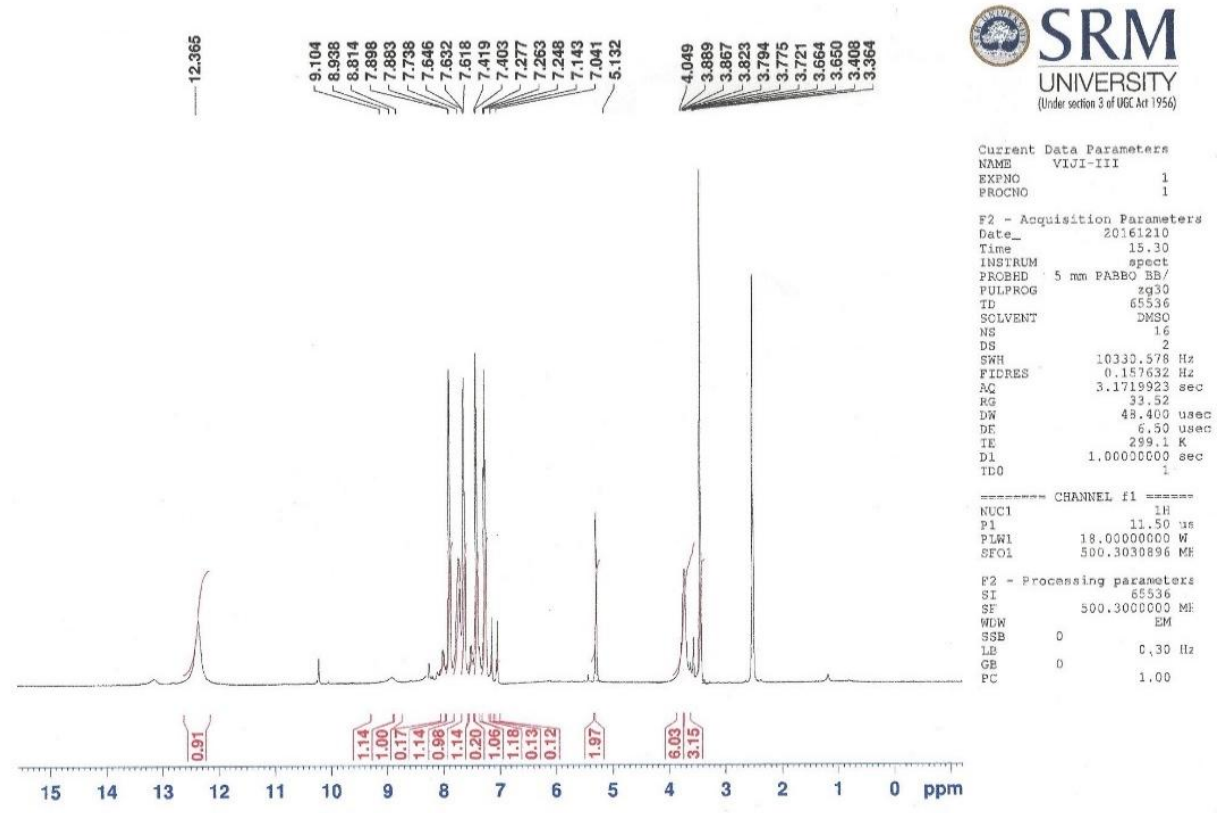

Fig 2:- ${ }^{1} \mathrm{H}$ - NMR spectrum of Baicalein-7-O-glucuronide from Persicaria glabra.
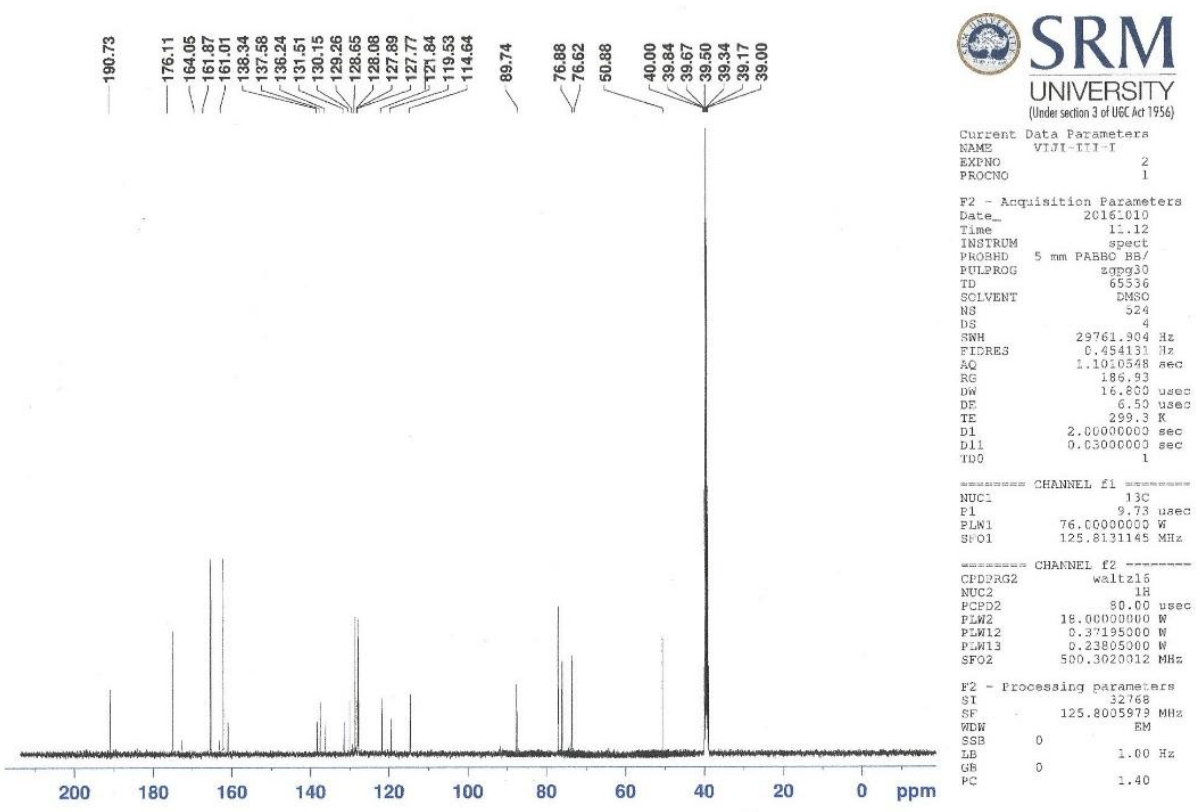

Fig 3:- ${ }^{13} \mathrm{C}$ - NMR spectrum of Baicalein-7-O-glucuronide from Persicaria glabra. 
Fig 5:- Photographic representations of control and experimentally induced ulcer model.

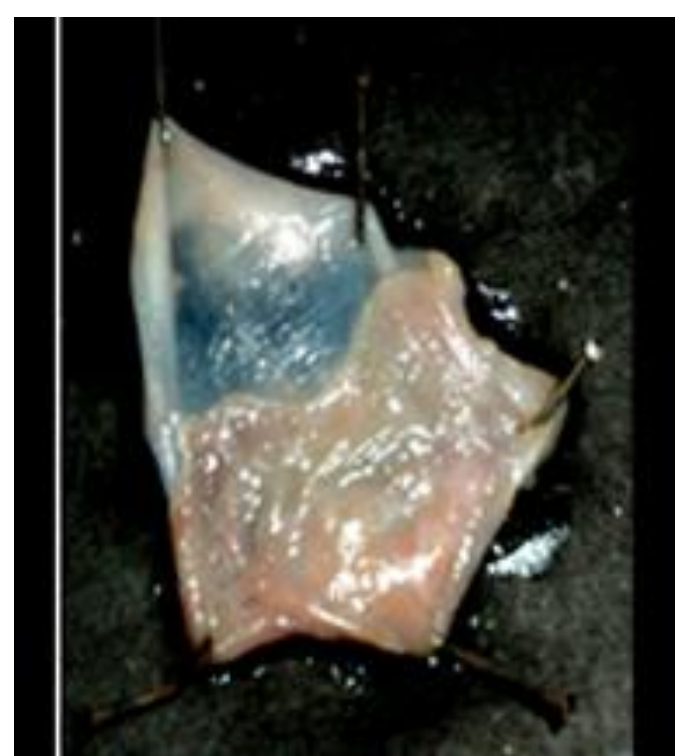

(a)

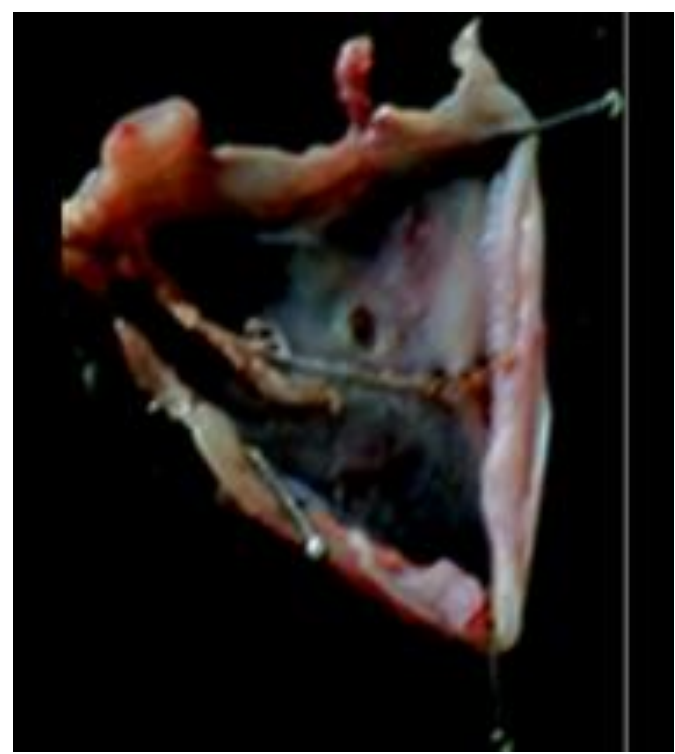

(c)

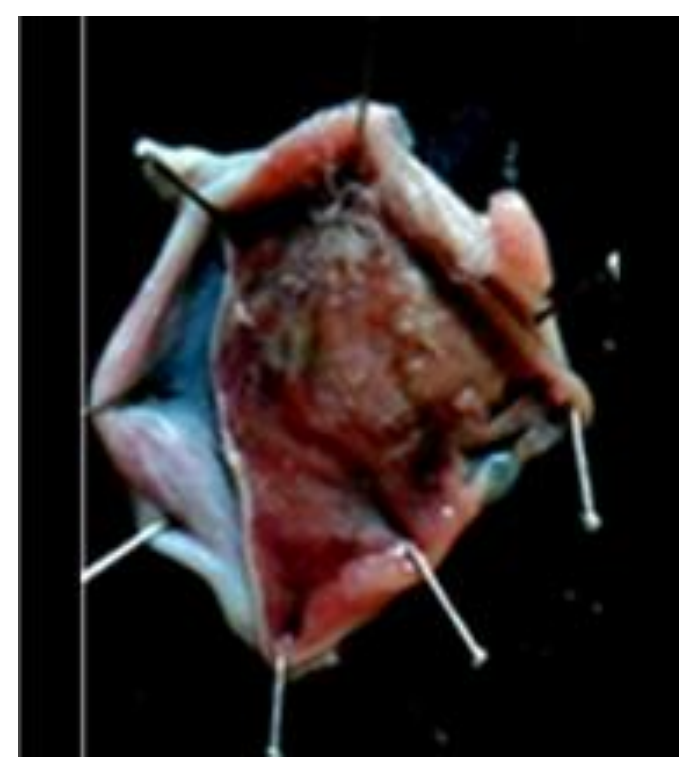

(b)

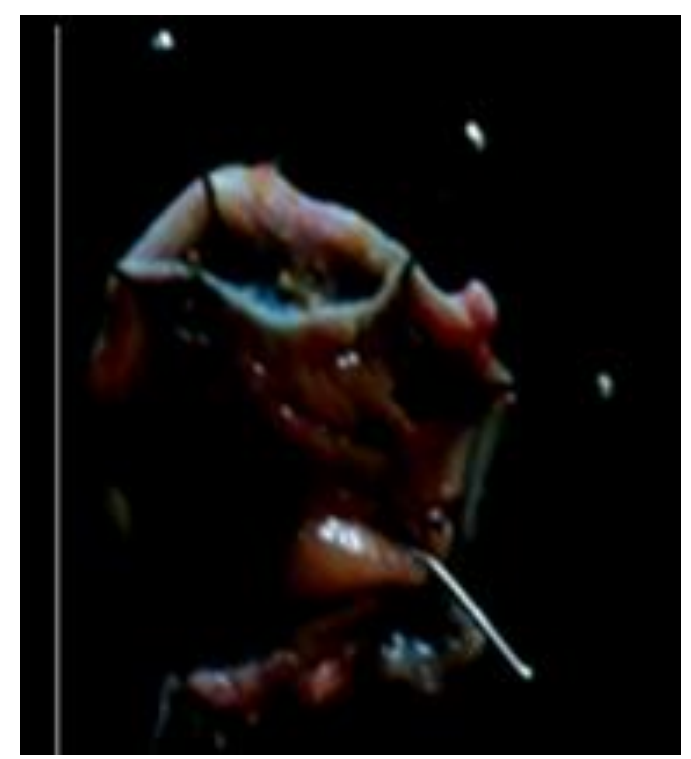

(d)

(a) Control; (b) Standard (Omeprazole): (c) Baicalein-7-O-glucuronide; (d) Methanolic extract 


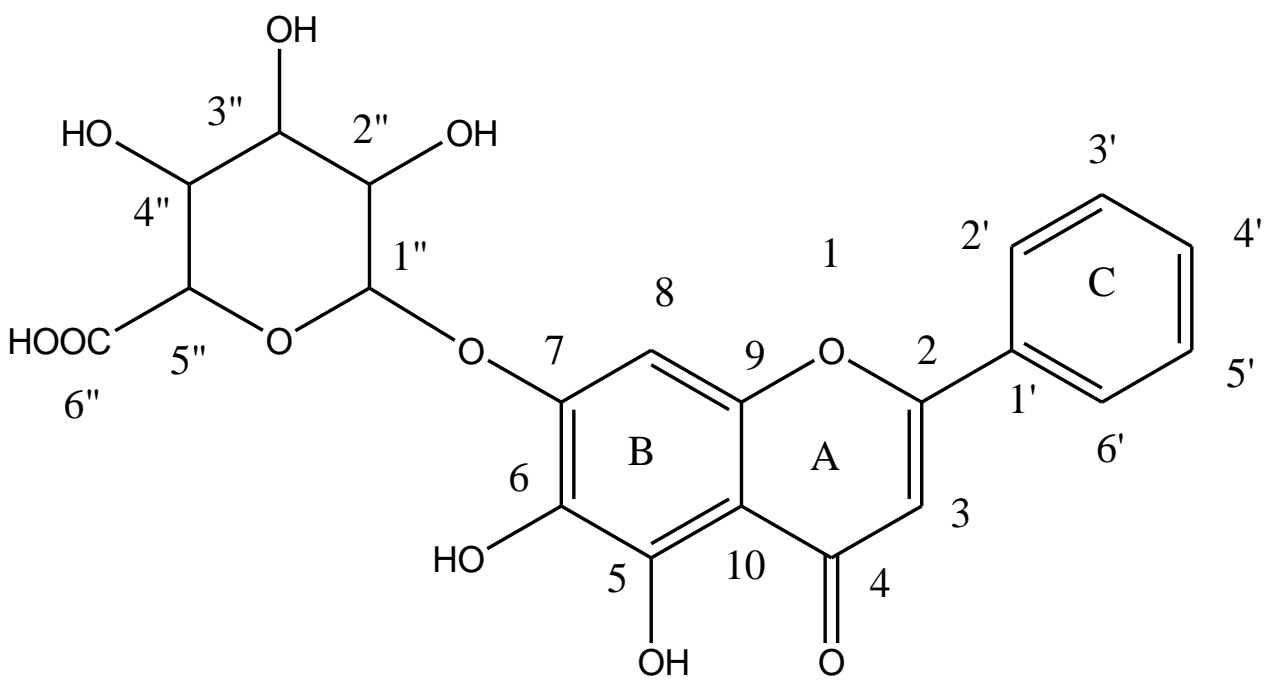

Fig 4:- Structure of Baicalein-7-O-glucuronide

Table 1:- Effect of Baicalein-7-O-glucuronide from Persicaria glabra on $\mathrm{pH}$, volume, acidity, ulcer lesion in control and experimental rats.

\begin{tabular}{|l|c|c|c|c|c|c|}
\hline \multicolumn{1}{|c|}{ Groups } & Ph & Volume & Free acidity & $\begin{array}{c}\text { Total } \\
\text { Acidity }\end{array}$ & $\begin{array}{c}\text { Gastric Ulcer } \\
\text { lesion }\end{array}$ & $\begin{array}{c}\text { \% of Ulcer } \\
\text { protection }\end{array}$ \\
\hline $\begin{array}{l}\text { Group I } \\
\text { (Control) }\end{array}$ & $2.8 \pm 0.34$ & $1.0 \pm 0.13$ & $225 \pm 14.4$ & $252 \pm 20.2$ & $1 \pm 0.03$ & - \\
\hline $\begin{array}{l}\text { Group II } \\
(\text { Omeprazole } 30 \mathrm{mg} / \mathrm{kg})\end{array}$ & $2.3 \pm 0.14^{\mathrm{b}}$ & $1.0 \pm 0.06^{\mathrm{b}}$ & $226 \pm 8.4^{\mathrm{b}}$ & $256 \pm 11.2^{\mathrm{b}}$ & $21 \pm 0.28^{\mathrm{b}}$ & 94.80 \\
\hline $\begin{array}{l}\text { Group III } \\
\text { (Baicalein-7-O- } \\
\text { glucuronide 250mg) }\end{array}$ & $2.9 \pm 0.15^{\mathrm{b}}$ & $1.2 \pm 0.05^{\mathrm{b}}$ & $216 \pm 7.7^{\mathrm{b}}$ & $270 \pm 11.9^{\mathrm{b}}$ & $1 \pm 0.07^{\mathrm{b}}$ & 90.37 \\
\hline $\begin{array}{l}\text { Group IV } \\
\text { (Methanolic extract } \\
\text { 500mg) }\end{array}$ & $2.8 \pm 0.17^{\mathrm{b}}$ & $1.4 \pm 0.06^{\mathrm{b}}$ & $218 \pm 9.6^{\mathrm{b}}$ & $272 \pm 12.6^{\mathrm{b}}$ & $1 \pm 0.08^{\mathrm{b}}$ & 89.63 \\
\end{tabular}

\section{Results and Discussion:-}

\section{Chemical constituents:-}

Baicalein-7-O-glucuronide has been isolated from the flowers of Persicaria glabra. Its melting points $\left(203^{\circ} \mathrm{C}\right)$ were compared with pure chemical of Baicalein-7-O-glucuronide (98\%) purchased from Sigma Aldrich Co (India) as external standard and originate to have the same values. The UV spectrum of the compound demonstrated two absorption peaks at $331 \mathrm{~nm}$ and $230 \mathrm{~nm}$ screening a flavone skeleton. The flavone oxygenated in A - ring, but not in the B - ring, tends to stretch spectra in methanol with an predictable band II and a weak band I. This compound revealed diagnostic IR absorptions at $3312 \mathrm{~cm}^{-1}(-\mathrm{OH}), 1653 \mathrm{~cm}^{-1}(>\mathrm{C}=\mathrm{O}), 2834 \mathrm{~cm}^{-1}$ (aliphatic C-H), $2945-2982$ $\mathrm{cm}^{-1}$ (aromatic $\left.\mathrm{C}-\mathrm{H}\right), 1448 \mathrm{~cm}^{-1}\left(\mathrm{C}=\mathrm{C}\right.$, aromatic) and $1108 \mathrm{~cm}^{-1}$ (C-O-C, vibration). HPLC analysis exhibited the presence of a flavone glycoside. The identified peak with the retention time of $13.88 \mathrm{~min}$ (Fig 1). ${ }^{1} \mathrm{H}-\mathrm{NMR}$ spectrum (Figure 2) showed multiplet signals at $\delta 8.93-\delta 7.14 \mathrm{ppm}(\mathrm{m}, 6 \mathrm{H}, \mathrm{Ar}$ ) assigned to aromatic protons and also showed signals at $\delta 9.10 \mathrm{ppm}$ (bs, 1-OH in acid) assigned to $-\mathrm{OH}$ in carboxylic acid group. In addition, ${ }^{1} \mathrm{H}-\mathrm{NMR}$ showed a signal at $\delta 5.13(\mathrm{~s}, 1 \mathrm{H}$, vinyl) assigned to vinyl proton. The 5-OH proton resonates at $\delta 12.36 \mathrm{ppm}$ (bs, 1 $\mathrm{OH}$ in $5^{\text {th }}$ position). The multiplet signals at $\delta 3.88-\delta 3.36 \mathrm{ppm}(\mathrm{m}$, unresolved, pyranose protons) assigned to the sugar protons. The ${ }^{13} \mathrm{C}-\mathrm{NMR}$ data (Figure 3) shown that were 21 carbons in this structure, 15 of which were typical for a flavone skeleton and the others were consigned to glycoside. ${ }^{13} \mathrm{C}$-NMR signal appear at $\delta 190.7 \mathrm{ppm}$ indicates that $>\mathrm{C}=\mathrm{O}$ at $\mathrm{C}-4$. The sugar carbon signals revealed $\delta 119.5,114.6,89.7,76.8,76.6$ and $50.8 \mathrm{ppm}$ are similar with those reported for $O$ - glucoside (Li et al., 2003). The ${ }^{1} \mathrm{H}$ NMR spectrum shown the presence of anomeric proton 
signal at $\delta 5.13$ ppm specified the presence of $O$ - linked sugar. It has established that the sugar moiety bonded to hydroxyl group at C-7 of the aglycone as assumed from the correlation between the anomeric proton at $\delta 5.13$ ppm and the C-7 at $\delta 138.3$ ppm (Kumar Roy et al., 2007).

By associating all the above exposed physical and chemical part of evidences the flavonoid found from Persicaria glabra flowers has been characterized as the Baicalein-7-O-glucuronide (Fig 4).

\section{Pyloric Ligation induced ulcer in albino rats:-}

The ulcer formation in each of these models occurs by different mechanisms pylorus ligation-induced ulcers are caused by enhanced acid pepsin secretion leading to auto-digestion of the gastric mucosa and break down of the gastric mucosal barrier, and the digestive effect of accumulated gastric juice and interference of gastric blood circulation are responsible for the induction of ulceration (Aditi Chaturvedi et al., 2007). The effect of orally administered four groups on gastric damage induced by pyloric ligation is shown in Table 1 . It was detected that increase the ulcer lesion in ulcer control rats. Significant reduction in ulcer lesion was observed in treatment with four groups. It is significant to note that increased the volume, total acidity and free acidity and decreased $\mathrm{pH}$ of gastric juice were observed in ulcer control rats as compared to normal rats. Administration of Baicalein-7-Oglucuronide decreased the volume, total acidity and free acidity and increased $\mathrm{pH}$ of gastric juice were observed as compared to control rats. Animal groups treated with the Baicalein-7-O-glucuronide exhibited a reduction of gastric damage against pyloric ligation induced gastric ulceration. The percentage of ulcer protection was $94.80 \%$ for Group 2, 90.37\% for Group 3, 89.63\% for Group 4 were recorded. Omeperazole, the positive control included for the study also offered significant protection $(94.80 \%)$ against pyloric ligation induced gastric ulcer. Figure 5 shows the photographic representation of control and experimentally induced ulcer model. The increase in volume in the ulcer control rats is undoubtedly due to increase protection of hydrochloric acid as evident from the total acidity and decrease $\mathrm{pH}$ value of gastric juice. In the present study, the decrease in volume of the gastric juice and concomitant decrease in the acidity and increase in $\mathrm{pH}$ proving the anti-ulcer activity of Baicalein-7-O-glucuronide. Further evidenced by the reduced edema formation and epithelial lifting were observed in morphometric study (Fig 5). Therefore, it can be believed that Baicalein-7-O-glucuronide may stimulate the secretion of prostaglandin or possess prostaglandin like substances.

\section{Conclusion:-}

Gastro protective role for Baicalein-7-O-glucuronide against gastric mucosal damage induced by pyloric ligation were investigated in the present study. Pyloric ligation induced gastric ulcer rats show increased gastric volume, acidity and depleted $\mathrm{pH}$. The observed gastro protection is possible mediated to a major extent by a gastric mucosal secretion mechanism as the isolated compound Baicalein-7-O-glucuronide are able to restore the increased volume, acidity and depleted $\mathrm{pH}$ by pyloric ligation almost towards normal levels seen in control. This is further evidenced by morphometric study.

\section{Conflict of Interest:-}

The authors declare no conflict of interest.

\section{References:-}

1. Aditi Chaturvedi, M., Mohan kumar, G., Bhavani, Harish Chaturvedi. and Mohan Kumar Goel, R.K. (2007): Effect of ethanolic extract of Eugenia jambolana seeds on gastric ulceration and secretion in rats: Indian J. Physiol. Pharmacol., 51(2): 131.

2. Alaghawani, W. and Naser, I. (2013): Study the hypoglycemic effect of Crataegus laevigata in Diabetic Rats. International Journal of Pharmaceutical and Clinical Research, 5(4): 145-149.

3. Anoop, A. and Jegadeesan, M. (2003): Biochemical studies on the anti-ulcerogenic potential of Hemidesmus indicus. J. Ethnopharmacol, 84: 149-156.

4. Harborne, J.B. (1994): Flavone and flavone glycosides, In The flavonoids: Advances in Research since 1986. Chapman \& Hall, Cambridge, UK, pp. 337-385.

5. Harold, Kalant, Grant, Denis, M., Mitchel. and Jane. (2007): In: Principles of Medical Pharmacology. Seventh Edn. Elsevier Canada Ltd., pp. 557-559.

6. Hirohashi, M.K., Takasuna, Y., Kasi, C., Usui, K., Tamura, S. and Kojima, H. (1993): General pharmacological profile of the new anti-ulcer drug 3-amino-N-methyl benzamide. Drug Res., 43: 569. 
7. Kumar Roy, M., Nakahara, K., Nathalang, V., Trakoontivakorn, G., Takenaka, M., Isobe, S. and Tsushidat, T. (2007): Baicalein, a flavonoid extracted from a methanolic extract of Oroxylum indicum inhibits proliferation of a cancer cell line in vitro via induction of apoptosis. Pharmazie, 62: 149-153.

8. Li, R.W., Myers, S.P., Leach, D.N., Lin, G.D. and Leach, G. (2003): A cross cultural study: anti-inflammatory activity of Australian and Chinese plants. J. Ethnopharmacol., 85: 25-32.

9. Nguelefack, T.B., Watcho, P., Wansi, S.L., Nguelta, M.M., Ngamaga, D., Tane, P. and Kamanyi, A. (2005): The anti-ulcer effects of the methanol extract of the leaves of Aspilia africana (asteraceae) in rats. African J. of Trad. Compl. and Alt. Medicine, 2: 233.

10. Sairam, K., Priyambda, S., Aryya, N.C. and Goel, R.K. (2003): Gastro duodenal ulcer protective activity of Asparagus racemosus: An Experimental, biochemical and histological study. Journal of Ethanopharmacolgy, 86: 1.

11. Sivakumar, P., Senthilkumar, K.L. and Praveen Varma, J. (2011): Phytochemical studies on Polygonum glabrum (Willd.). International Journal of Pharma and Bio Sciences, 2(2): 169-175.

12. Turner, R.A. (1965): Screening methods in pharmacology. New York: Academic press, pp. 302-304. 